Jelena R. Tasić

Energoprojekt, Belgrade Serbia

Milan Gojak

Asociate Professor

University of Belgrade

Faculty of Mechanical Engineering

Nenad Lj. Ćuprić

Asociate Professo University of Belgrade

Faculty of Forestry

Milan R. Božović

Asociate Professor University of Pristine

Faculty of Agricurtural

\section{Active Solar Dryer for Biological Materials}

This paper presents an original design and construction of a small scale, mobile, universal, ecological, chamber, active, dryer for drying medicinal and aromatic plants and non-timber forest products. The drying process uses only solar energy. The drying agent is a mixture of hot pure air and already used drying agent from the drying chamber exhaust. Pure air is heated in flat plate solar collectors and it is pulled by an electrical fan placed on the top of the drying chamber. The mobility of the collectors and dryer provides optimal utilization of sun energy throughout the day. $P V$ modules, placed on the roof of the dryer, generate all necessary electric power for the fan, the control system and charge a set of accumulators during the day. Experimental results and kinetics of the drying process obtained by the solar dryer prototype are also given.

Keywords: Mobile solar dryer, flat plate solar collector, Drying chamber, Drying kinetics

\section{INTRODUCTION}

Today solar energy is used to dry various food products such as: grains, fruits, vegetables, fish, meat, salt etc. The drying process makes non-timber forest products (fungi, edible wild fruits and nuts), medicinal and aromatic plants more stable for safe long term storage [1].

That means storage conditions which prevent possibilities for loss of color, development of unwanted smells and tastes, unwanted chemical changes which devastate product utilization or suitability for further processing, mold and microorganism development which causes formation of toxic substances like aflatoxin and the other mycotoxins. It is estimated that about $12 \%$ of the total energy used by industry appertains to drying processes. Usage of solar energy for the drying could significantly reduce $\mathrm{CO}_{2}$ emission, enable drying in the field or near the preparation area and makes the whole process cheaper.

Drying food by placing the food on mats in the sun is in use for thousands of years. In [2] give a short historical description of solar drying through the centuries. Today, numerous types of solar dryers have been designed and developed all over the world. Many studies deal with solar dryer constructions and application of solar drying in agricultural and other food industry products [3], [4]. In [5] and [6] reviews of types of solar dryers in view of the product being dried, technical and economical aspects were presented. Ekechukwu and Norton [7] present a complete classification of solar dryer types and review on various designs, construction and operation principles. In [8], a review of various solar drying technologies is presented. Four types of solar dryers are in use: direct

Received: January 2018, Accepted: April 2018

Correspondence to: $\mathrm{mr}$ Jelena Tasić

Energoprojekt, Bulevar Mihajla Pupina 12,

Belgrade, Serbia

E-mail: jelenat2281@gmail.com

doi: $\mathbf{1 0 . 5 9 3 7 / f m e t 1 8 0 4 5 3 7 T}$

(C) Faculty of Mechanical Engineering, Belgrade. All rights reserved solar dryers, indirect solar dryers, mixed-mode dryers and hybrid solar dryers [4]. Various constructions of small scale modular indirect solar dryers, which mainly consist of a solar air heater and a drying chamber, have been developed and analyzed. In [10] an originally designed solar dryer is presented which was installed on the Pilot Plant of the Solar Energy Institute, Ege University, Turkey. In [11] a small scale modular solar dryer is presented and its features and operational characteristics were analyzed. El-Sebaii et al, [12] presented an indirect type natural convection solar dryer designed, constructed and operated under Tanta, Egypt, prevailing weather conditions. A review of other similar passive and active solar dryers is given in [13].

The main characteristic of solar indirect dryers is the use of solar energy for preparation of the drying agent [5], Goyal and Tiwari, [14] Goyal and Tiwari, [15]. Compared to drying directly with solar radiation, the drying material in indirect dryers is protected from dirt, insects, dew, rainfall and other possible outside influences. These dryers also enable better preservation and keep the nutritious and biological value of the drying material, which is very important for high quality of the final product. Compared to direct dryers, indirect dryers are capable of concentrating solar energy. It is also possible to increase the collector surface and air flow through the collector enabling indirect dryers to attain almost optimal working parameters in different climate and weather conditions.

In accordance with the way the drying agent flows, solar dryers are classified as solar dryers with a natural flow - "passive dryers", and solar dryers with a forced flow - "active dryers". From the aspect of capacity, solar dryers are classified as [5]:

- Small capacity solar dryers - dry up to $150 \mathrm{~kg}$ of dried products per month,

- Medium

- Large capacity solar dryers - dry up to $4500 \mathrm{~kg}$ or more dried products per month. 
Solar dryers can use additional energy sources such as photovoltaic (PV) modules or small wind generators for generating electricity for a fan and other electrical devices. A review of small scale solar driers with improved technologies in the Asia-Pacific region is given in [16] and [3].

They also have differently constructed drying chambers. Solar dryers enable a significantly shorter drying time, higher productivity and lower product cost.

Besides that, solar dryers have some disadvantages. They are not efficient on a cloudy day. A cold or damp climate is a problem too, as it is difficult to provide the necessary amount of warm air - the drying agent, to effectively dry the material before it starts to spoil. During good weather overheating is possible, causing damage to the drying material. Only control of the drying regime can prevent this [5].

\section{MATERIAL AND METODS}

\subsection{Justificion for solution}

The following facts indicate the need and justification for designing a solar, mobile, active, ecological, universal dryer for drying biological materials $[16,17]$ :

- The intensity of solar radiation is the highest at the same time agricultural cultures are harvested, from late spring to the late autumn,

- Geographical position of Serbia and other Central European countries is favorable with a lot of sunny days,

- Different kinds of food are dried: fruit, vegetables, aromatic plants, spices, fungi and other eatable products,

- Most materials must be dried immediately after picking in order to preserve quality,

- The interest for dried biological material has grown all around the world,

- These cultures grow far from urban areas where it is hard to deliver expensive fossil fuel and electricity,

- Energy saving and indirect drying methods are required,

- The requirement for clean technologies and quality dried products is more expressed,

-When using solar dryers, the only and highest item is the investment value and costs of dryer construction,

-From the economic and ecologic aspect a solar dried product is more competitive compared to products dried in classical fuel dryers,

The period from April to October is the time for collecting spice, medicinal and aromatic plants, and also non- timber forest products [16], [17]. Every plant has an optimal time for harvesting or collecting. That time depends on the part of the plant which is used as a drug or a spice - product.

This solar dryer is intended for farms that have an arable land of about 0.5 ha under medicinal herbs, aromatic plants and spice cultures. It is also useful for non-timber forest products: fungi, edible wild fruits and nuts and other natural products.
A mobile, universal, ecological, chamber, active dryer for drying biological material using solar energy, is a compact mobile unit mounted on a single-axle trailer. Its mobility enables transportation to the working location and fast transformation from transportation to the working position. The presented concept provides the most favorable solar energy reception, better quality of the dried material and energy saving.

Basic characteristics of the solar dryer are $[16,17]$ :

- It is a chamber type with a periodical working regime,

- The dryer can operate at any location,

- The drying material is stationary, spread on plates placed one above the other inside the drying chamber,

- The drying agent is a mixture of pure air heated in flat collectors of solar energy and already used air from the drying chamber,

- $\quad$ Possible regulation of the drying process regime by recycling the drying agent,

- Softer drying regime,

- Enables a standing time of the material during the drying process.

- The drying agent flows around and through plates during the drying process,

- Movement of the drying agent is natural or forced by using the fan,

- Flat collectors are adjustable in position and slope,

- Two accumulators built-in at the rear of the trailer supply the electromotor of the fan and they are recharged by electric energy generated in PV panels,

- Low operating costs,

- Universality, different materials could be dried

Based on the presented concept of the solar dryer a dryer module prototype has been made, (Figure. 1).

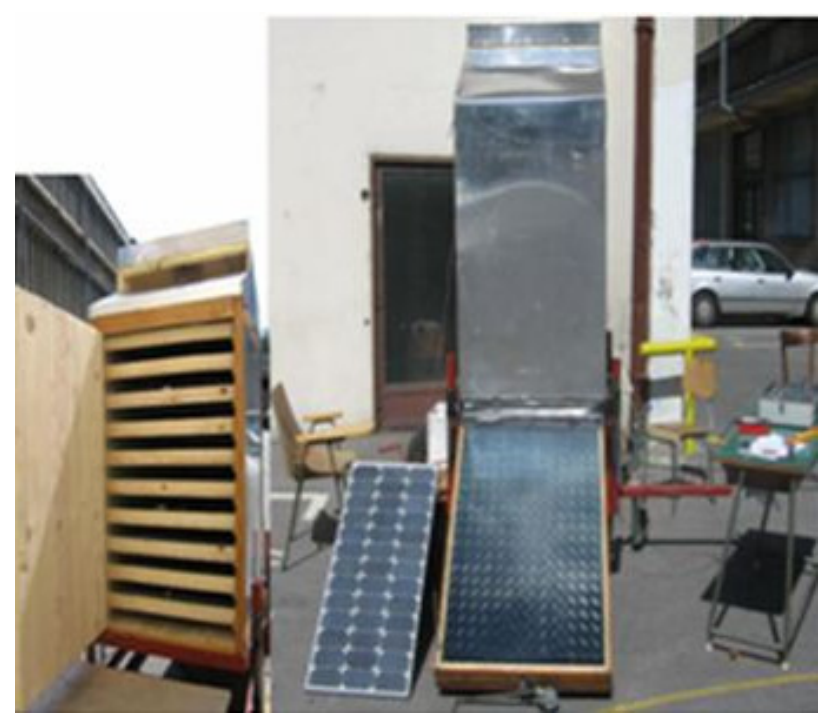

Figure 1. Prototype of one module of the solar dryer

The basic dryer components are: a rectangular prismatic drying chamber with 10 plates placed one above the other, the solar energy collector and the single-axle - the mobile dryer in the narrower sense. The 
chamber and collector are made of wood and covered by an aluminum sheet.

The collector receiver is covered with glass A hydraulic jack used for vertical positioning of the chamber to the height that corresponds to the optimal angle of the solar energy collector, depending on the location and conditions, is built-in at the middle of the trailer. The front jack with a small wheel enables the trailer to be rotated into the most favorable position depending on the spreading angle of solar radiation during the day. The solar energy collector is hinge connected to the frame of the drying chamber. The simplest way for determining the optimal position and angle is by the shadow of a rod perpendicularly mounted on the frame of the solar energy collector.

The basic technical characteristics of the dryer module are given in Table 1. A photovoltaic panel (PV) is used to provide electrical energy and it is directly connected with the centrifugal ventilator. The PV module has a power of $\mathrm{N}=75 \mathrm{~W}$ and surface of $\mathrm{F}=0.66 \mathrm{~m}^{2}$.

On Figure. 2. a plate for placing the drying material is presented. Plates are made of a double wooden frame (1 and 2) with a metal mash (3) in between. Part of the plate, about $50 \mathrm{~mm}$ length, is separated to obtain circulation of the drying agent around the plate together with flow through the mash. It is possible to stop circulation by closing that part with a lid (4) or with the drying material. Inside the drying chamber, plates are supported by their longer side with alternately facing openings for circulation. Based on their dimensions, number and recommended distance between them, the chamber dimensions and dimensions of the whole dryer are defined $[16,17]$.

Table 1. Dimensions of the basic prototype components

\begin{tabular}{cc}
\hline Component & $\begin{array}{c}\text { Dimensions } \\
\text { [mm] }\end{array}$ \\
\hline Trailer (wide/long) & $1300 \times 2650$ \\
Drying chamber & $800 \times 1000 \times 1200$ \\
Collector & $805 \times 1180$ \\
Plate (useful) & $800 \times 1000(760 \times 920)$ \\
Max. and min. height of the \\
drying chamber in the \\
working position
\end{tabular}

The solar air heater is the most important component of the indirect solar drying system. The double-side flat plate solar collector, shown on Fig. 3, is used for heating the drying agent. It consists of two wooden frames (1 and 2).

The rod for defining the optimal position is perpendicularly mounted on the collector's upper frame (not presented). The collector overall dimensions are: $868 \times 1268 \times 134 \mathrm{~mm}$. The solar radiation absorber (6) is made of $1 \mathrm{~mm}$ thickness ribbed aluminum sheets, painted with black matte paint. Its dimensions are The solar collector is covered with glass (7). The absorber divides the collector in two canals $50 \mathrm{~mm}$ high. The air intake is on the top of the collector's back side (9). The collector through the opening on the top. Heated air goes inside the drying chamber all over its width. The air flow speed through the solar collector is changeable. The average value is about $1 \mathrm{~m} / \mathrm{s}$. The construction of the walls, the roof, the floor and the door prevents loss of heat from the dryer, Fig. 4. The walls consist of three parts: the outside is made of aluminum sheet $1 \mathrm{~mm}$ thickness (1), the inside is made of wood $21 \mathrm{~mm}$ thickness (3) and the air gap is in-between (2). This gap also allows the usage of already used drying agent from the chamber exhaust (7) for regulation of the drying agent temperature during the drying process. For that purpose a shutter with a flap (4) is installed at the entrance into the drying chamber and it is manually controlled on the prototype. It enables mixing of the air from the wall insulation space of the drying chamber with heated air from the collector in different ratios, maintaining the required temperature regime and humidity of the drying agent at the entrance into the drying chamber. The shutter on the chamber exhaust (8) on the roof gives additional control of the drying agent characteristics and it is manually controlled, too. The centrifugal ventilator (6) has three working speeds.

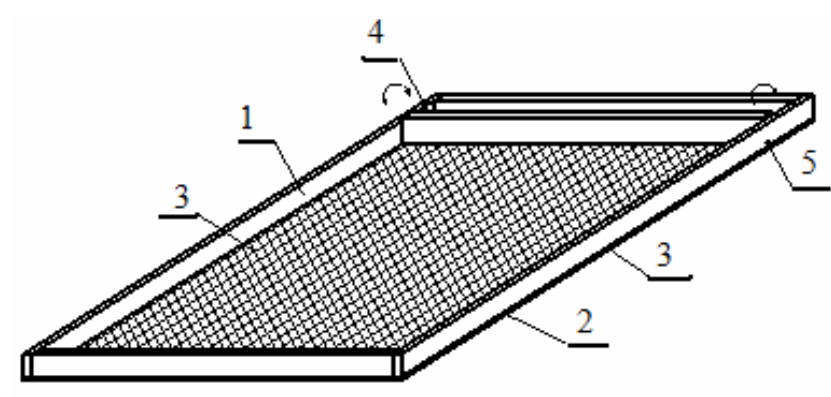

Figure 2. Plate for placing the drying material 1. The Upper frame, 2. Underneath frame, plate, 3. Metal mash, 4. Separated part for circulation.

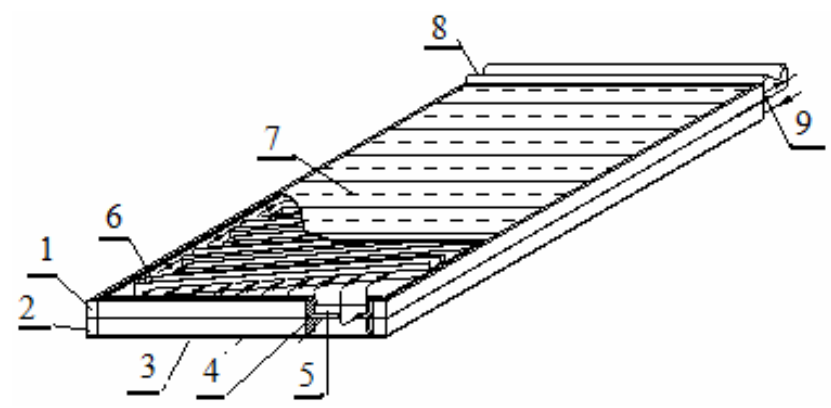

Figure 3. Construction of a double side flat

1. The upper frame, 2 . The lower frame, 3. Back cover, 4. Solar radiation absorber 5 . The drying agent, 6 . Collector $s$ filling, 7. The glass cover, 8. Elastic connection Between collector and drying chamber, 9. The fresh air intake.

The wall above the solar collector (9) is a reflective surface and it increases the effect of solar radiation on the solar collector. The roof, the floor and the door have similar construction with the air gap. Plates for placing the drying material (5) are placed with alternately facing openings for circulation, which enables optimal circulation of the drying agent around the plates.

The rod (10), perpendicularly mounted on the frame of the solar collector, is used for optimal positioning of the dryer and the solar collector. The optimal position is obtained by lifting or lowering the collector jack (11) or trailer jacks and by turning the whole dryer on the trailer. The mesh of concentric circles and lines in the base of the rod gives good orientation in positioning. 


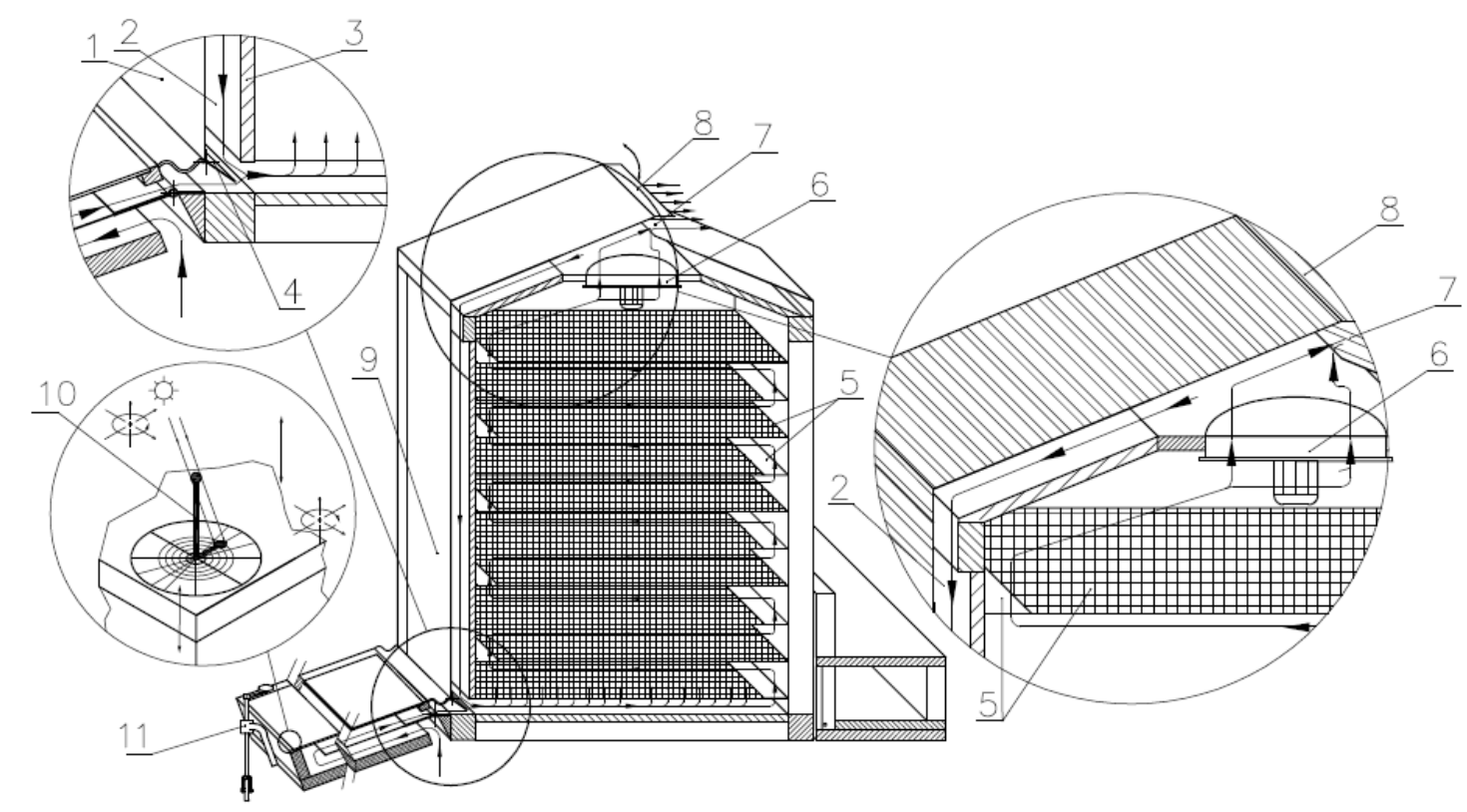

Figure 4. Cross section of the dryer chamber with walls enabling recirculation of the drying agent and regulation of the drying agent temperature Prototipe of one module of the solar dry

\section{OBTAINED EXPERIMENTAL RESULTS AND DISCUSSION}

\subsection{Experimental results}

Fresh leaves of Dutch spinach were used. This culture was chosen because of its: exceptionally high starting moisture (moisture content is $\mathrm{u}=9 \mathrm{~kg}_{w} / \mathrm{kg}_{\text {adm }}$ ), high ratio between the fresh and dried material 100/8 and availability during the whole year. The unit load of the plate surface with fresh material was $1.5 \mathrm{~kg}$. The experiment was performed on September, the $08^{\text {th }}$ and the $09^{\text {th }}, 2005$. The following parameters were measured: outside temperature $t_{e}$, temperature of the drying agent at the entrance into the drying chamber $t_{d a}$, temperature of the material $t_{m}$, flow velocity of the drying agent $v_{d a}$ and mass of the samples of drying material taken from representative plates: the 1st, the 4 th and the 7 th. The mass of the absolutely dry material was defined by drying a corresponding sample in a laboratory dryer using a standard method.

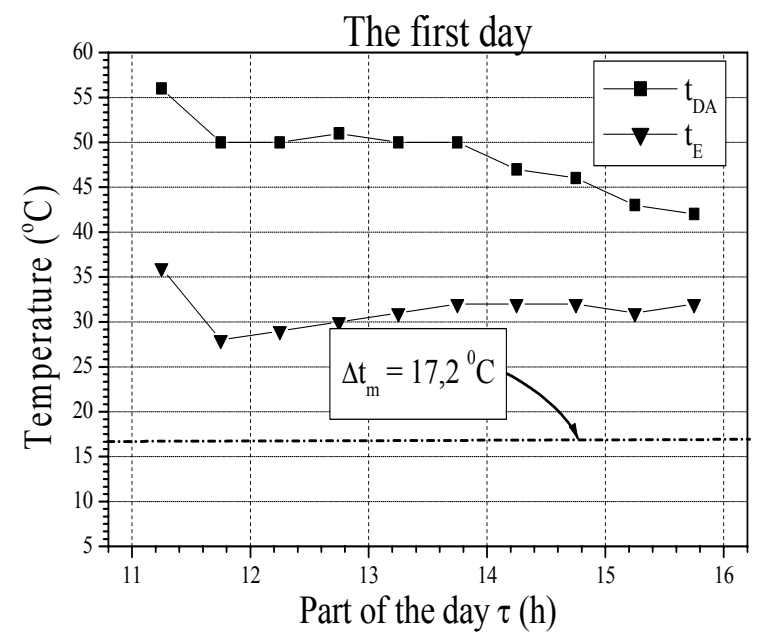

Figure 5. Temperature curves of the environment air and drying at the entrance into the drying chamber

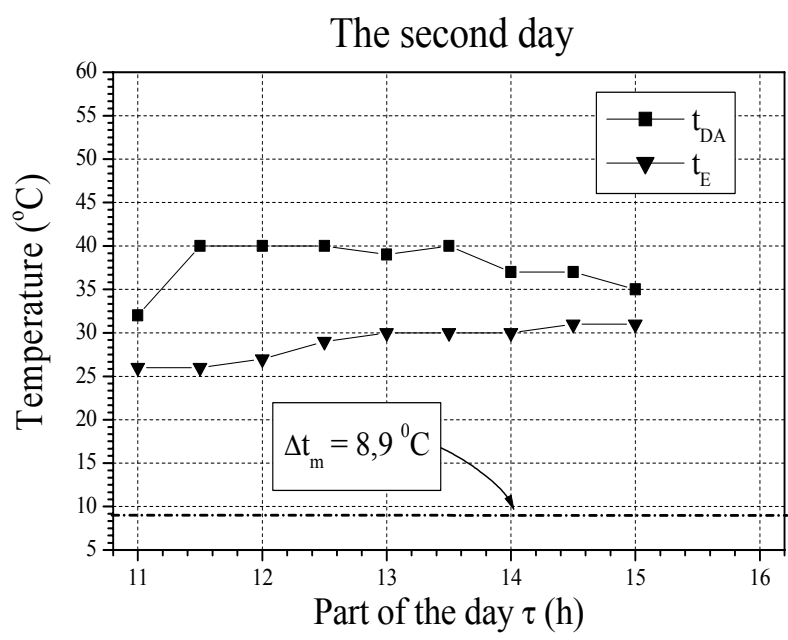

Figure 6. Temperature curves of the envoriment air and drying at the entrance into the drying chamber

The values of the outside air temperature $t_{e}$ and the drying agent temperature $t_{d a}$, measured during the day, are presented in Figure 5. and 6. The difference of mean values of these two temperatures on the first day was $\Delta t_{m}=17.2^{\circ} \mathrm{C}$ and on the second day, when it was cloudy, $\Delta t_{m}=8.9^{\circ} \mathrm{C}$.

The drying agent flow, one of the most important factors in the whole process, was measured using a propeller anemometer for measuring the velocity of the drying agent flow at the exit opening of the drying chamber.

The centrifugal ventilator was directly connected to the (PV). Electrical power, which was generated, depended on the solar radiation intensity and it caused unevenness of the velocity of the drying agent flow. During the first day (sunny day with short cloudy periods) the ventilator was set on the lowest speed, and the next day it was set on the highest speed (cloudy day). During the night the ventilator was obtained. The corresponding drying curves are given in Fig. 7. and 8, for the following conditions: 
- The mean value of the drying agent temperature during the first day was $t_{\text {dam }}=46.5^{\circ} \mathrm{C}$ and the second day was $t_{d a m I I}=37.778^{\circ} \mathrm{C}$;

- The mean value of the outside temperature during the first day was $t_{e m I}=31.3^{\circ} \mathrm{C}$ and the second day was $t_{e m I I}=28.8^{\circ} \mathrm{C}$.

- The mean value of relative humidity of the air during the first day was $\varphi_{e m I}=42.3 \%$ and the second day was $\varphi_{\text {emII }}=46.3 \%$.

In the experimental data, due to the inability of the exact measurements, there is a certain error, so it is necessary to analyze their impact on the quality of the results. In determining the performance of an experiment measuring the mass of material is done on a scale measuring accuracy $\pm 0.1 \mathrm{~g}$. Measurement error with this instrument si in the field of instrument. Measurement accuracy, resolution of the device indicates that the measurement error is negligible, there is no possibility of occurrence of subjective errors when reading as a display. Kinetics of drying material layer requires knowledge of the moisture content of the sample points in time, measuring the change in mass. It also measured the temperature of the sample during the experiment and the environment.

Determination of drying kinetics was performed as follows: the three measuring pans (I, IV and VII) There were bowls of raw material weight of $20 \mathrm{~g}$ of material which are measured on the analytical balance at a certain time.

To determine the moisture content the samples of $7.5 \mathrm{~g}$ were sued, and then dried at $105^{\circ} \mathrm{C}$ in the laboratory conditions to absolutely dry state, and then measured. Afterwards the measurement was done on the analytical balance of accuracy $\pm 0.0002 \mathrm{~g}$.

Measuring the temperature and the air layer was performed by thermocouples, which were isolated and placed outside the tube wall, which secured the position of each pair. Outside the tube was head of each of the thermocouples and wire (isolated from the outside), which provided that the measurement error due to the implementation can be neglected. All thermocouples were connected to termokompenzator. Absolute error converting the electromotive force in the compensated temperature including the reference temperature for the measured temperature range of 0 to $100{ }^{\circ} \mathrm{C}$ amounted to $+0.2{ }^{\circ} \mathrm{C}$. Measurement of ambient relative humidity (input to the receiver) was estimated using a psychrometer of Ashman.

\section{DISCUSSION AND CONCLUSIONS}

Two parameters were selected and presented here for evaluation of the operating quality of the solar energy collector and the whole solar dryer:

-Attained drying agent temperature measured on the collector exit,

-Difference between the drying agent temperature and the temperature of outside air on the collector entrance.

The results presented by the diagram in Fig. 5, and 6., show significant oscillations in temperature values and they are in accordance with the part of the day and also the occurrence of cloudy periods during the day.
These results definitely show that, although the weather conditions were not well and with long cloudy periods, obtained values of the drying agent temperature and its increase from starting values (the temperature of outside air) are high enough and the solar energy collector satisfied completely. The differences between temperatures of the drying agent and the outside air rise up over $20^{\circ} \mathrm{C}$.

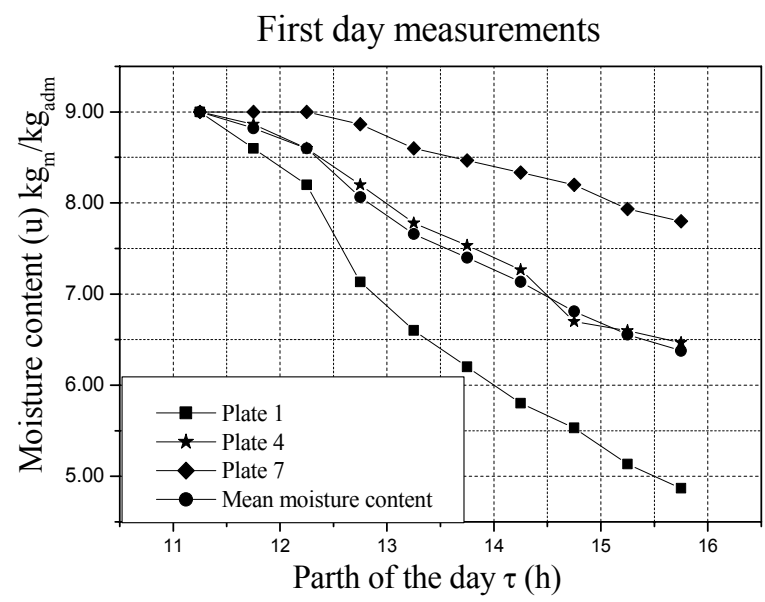

Figure 7. Drying curves for the first day

The presented drying curves on Figure. 7, and 8 . based on experimental results obtained on representative plates $1 \mathrm{st}, 4$ th and 7 th, give a clear picture of the unevenness of the drying process inside the drying chamber. This is the main disadvantage of all chamber dryers. For that reason, changing of plate positions during the drying process is usual in practice and it is necessary.

Also, it is obvious that a significant moisture reduction of the material occurred during the night Figure 7. and 8., when only natural circulation of air occurred. The mean value of moisture content decreased from 6.5 to $5 \mathrm{~kg}_{\mathrm{m}} / \mathrm{kg}_{\text {adm }}$, roughly. That is mainly a consequence of the construction and structure of boundary surfaces of the drying chamber.

Analysis of the material's drying curves Fig. 7. and 8 , gives a clear picture of the high moisture separation intensity from a moist material.

These results are the base for determination of the drying time and dryer capacity per separate amounts of moisture - the moisture flow.

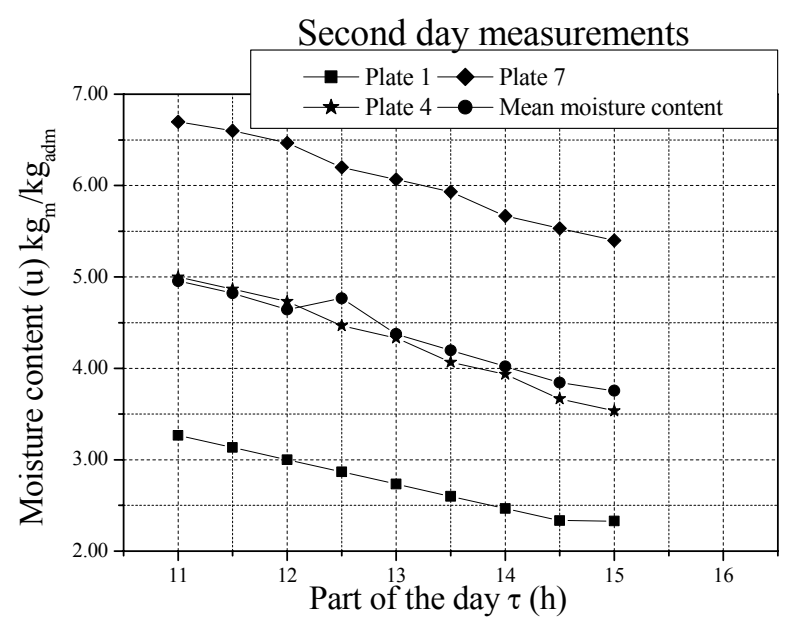

Figure 8. Drying curves for thesecond day 
Based on the measured values for outside air parameters and the drying agent parameters at the collector exit/entrance into the drying chamber, their mean values enable representation of the state of the air, drying agent, on an $\mathrm{x}-\mathrm{h}$ diagram and can be calculated during the experiment.

Also, it is possible to calculate [17], [18]:

-Volume flow of the drying agent through the drying chamber based on knowing values for the dimensions of the intake and the output openings of the solar collector and the mean value of the flow velocity of the drying agent,

-Enthalpy and the mass flow of the drying agent based on the thermo physical values of the drying agent,

-The mass flow of separated moisture from drying curves,

-Values of specific heat "consumption" based on values of heat flux and mass moisture flow.

Obtained values for the drying agent temperature, the velocity of the drying agent, corresponding flow rates of the drying agent and defined kinetic of the drying process show that this solar dryer can be successfully used for drying high quality products from fruits, vegetables, medicinal, aromatic and spice plants.

\section{CONCLUSIONS}

In the last decade ecological aspects have become more serious together with energy issues. Solving energy problems becomes very important from the ecological aspect, as activities in connection with energy are the main sources of environment pollution. That is the reason why renewable and clean energy sources are in the focus, with first of all, solar energy. Continual growth of energy needs and the fact that classical energy sources are limited in the interaction with rapid development of technical knowledge and technologies, with prior understanding of physical laws, contributed to the application of the solar energy.

This mobile, universal, ecological, chamber, active, dryer for drying different kinds of plants is designed to satisfy three basic requirements of the drying process: maximal process intensity, good quality of the dried material and minimal energy consumption. Its construction provides the following benefits:

- Operation at any location and universality,

- Insignificant exploitation costs,

-Possibility of drying products as soon as they are picked,

- The most favorable reception of solar radiation by following the Sun's apparent daily movement,

- Possibility of regulating the drying process regime by mixing pure hot air with the already used drying agent from the drying chamber,

- Better nutritious and biological values of dried products,

- Better economic effect as it uses free energy.

It is obvious that application of solar energy in drying processes is not just exchange of classical fuel with solar energy, but also a way for producing better quality products in a more economical way.
The presented results of the drying process of the solar dryer prototype definitely show that the obtained values of the drying agent temperature, the velocity of drying agent flow and drying kinetics are good enough for quality production of dried fruit, vegetables, fungi, medicinal and aromatic herbs and spices.

\section{NOMENCLATURES}

$\begin{array}{lll}\mathrm{M} & \text { mass of material } & \mathrm{Kg} \\ P V & \begin{array}{l}\text { photo voltaic } \\ \text { temperature of the drying agent }\end{array} & \\ t & { }^{\circ} \mathrm{C}, \\ u & \text { and material } & \text { moisture content, d.b. } \\ \mathrm{Y} & \text { moisture content w.b. } & \mathrm{kg} \mathrm{kg}^{-1} \\ \mathrm{I} & \text { first day } & \\ \text { II } & \text { second day } & \end{array}$

\section{Subscripts}

$\begin{array}{ll}a d m & \text { absolutely dry material } \\ d a & \text { drying agent } \\ \text { Dir } & \text { Directly } \\ \text { Dif } & \text { Diffuse } \\ \text { E } & \text { environment } \\ m & \text { mean value }\end{array}$

\section{REFERENCES}

[1] Topić M. R.,2002. Direct use of Solar Energy for drying medicinal herbs, aromatic plants and spices, Proceedings of SETT- 2002 - Moscow, Russia, Volume 2, 130-135.

[2] Belessiotis, V., Delyannis, E., 2011. Solar drying, Solar Energy, 85, 1665-1691.

[3] Jairay, K.S., Singh, S.P., Srikant, K., 2009. A review of solar dryers developed for grape drying, Solar Energy,83, 1698-1712.

[4] Fudholi, A, Sopian, K., Ruslan, M.H., Alghoul, M.A., Sulaiman, M.Y., 2010. Review of solar dryers for agricultural and marine products, Renewable and Sustainable Energy Reviews, 14, $1-30$.

[5] Gregoire, G.R., 1984. Understanding solar food dryers, Volunteers in Technical Assistance (VITA), Virginia, USA.

[6] El-Sebaii, A.A., Shalabyb, S.M., 2012. Solar drying of agricultural products: A review, Renewable and Sustainable Energy Reviews, 16, 37-43.

[7] Ekechukwua, O.V., Norton, B., 1999. Review of solar- energy drying systems II: an overview of solar drying technology, Energy Conversion \& Management, 40, 615-655.

[8] Raman Viyaya V. S., Iniyan, S., Goic, R., 2012: A review of solar drying technologies, Renewable and Sustainable Energy Reviews, 16, 2652- 2670.

[9] Tiris, C., Tiris, M., Dincer, I., 1995. Investigation of the thermal efficiencies of a solar dryer, Energy Conversion and Management, 36 (3), 205-212.

[10]Farkas, I., Seres, I., Meszaros, C.S., 1999: Analytical and experimental study of a modular solar dryer, Renewable Energy, 16, 773-778. 
[11]El Sebaii, A.A., Aboul-Enein, S., Ramadan,M.R.I., Gohary, H.G., 2002. Experimental investigation of an indirect type natural convection solar dryer, Energy Conversion and Management, 43, 22512266.

[12] Sharma, A., Chen, C.R., Vu Lan, N., 2009. Solarenergy drying systems: A review, Renewable and Sustainable Energy Reviews, 13, 1185-1210.

[13] Goyal, R.K., Tiwari, G.N., 1997. Parametric study of a reverse flat-plate absorber cabinet dryer: a new concept. Solar Energy 60 (1), 41-48.

[14] Goyal RK, Tiwari GN. 1999. Performance of a reverse flat plate absorber cabinet dryer: a new concept, Energy Conversion \& Management, 40 (4), 385-392.

[15] Ramana Murthy, M.V., 2009. A review of new technologies, models and experimental investigations of solar driers, Renewable and Sustainable Energy Reviews, 13, 835-844.

[16] Topić M. R., Petrović Lj. A., Ćuprić Lj. N., Dedić, A. 2004, Development and research of mobile solar dryer for biological materials, Project No. 211068, Ministry of science and the environment Republic of Serbia

[17] Topić M. R., Petrović Lj. A., Ćuprić Lj. N., 2005.Presentation of a solution of a mobile universal solar dryer for drying biological materials, Proceedings of the 12th symposium of thermal engineers (CD), Sokobanja, Serbia (in Serbian).
[18]Ivan J. Zlatanović,Miloš B. Pajić,Dragana V. Rančić, Zora Dajić Stevanović, Dragana Č. Dudić: Drying Kinetics and Shrinkage Analysis of Valeriana Officinalis Roots, FME Transactions, Vol. 45, No. 1, pp. 142-148, 2017

\section{АКТИВНА СОЛАРНА СУШАРА ЗА БИОЛОШКЕ МАТЕРИЈАЛЕ}

\section{Ј. Тасић, М. Гојак, Н. Ћупрић, М. Божовић}

У овом раду се приказује оригинално решење мале, покретне, универзалне, еколошке, коморне, активне сушаре за сушење биолошких материјала, лековитог, ароматичног и зачинског биља. Процес сушења се остварује соларном енергијом. Агенс сушења је ссмеша свежег ваздуха и израђеног агенса сушења. Свеж ваздух се загрева у равном соларном пријемнику и транспортује се до коморе за сушење и кроз комору за сушење вентилатором постављеним на врху коморе за сушење. Промена положаја сушаре и пријемника омогућава оптимални пријем соларне енергије током целог дана. PV модули, постављени на крову сушаре, обезбеђују потребну електричну енергију за погон вентилатора, система за контролу и за пуњење две акумаулаторске батерије.У раду су такође приказани и резултати експерименталних истраживања кинетике процеса сушења, која су изведена на прототипу соларне сушаре. 